\title{
Impact of resource conservation technologies on soil health and productivity of wheat in rice-wheat cropping system
}

\author{
Sanjay Kumar Mandal ${ }^{1}$, Rakesh Kumar ${ }^{1 *}$, Amarendra Kumar ${ }^{2}$, Sanjay Kumar ${ }^{3}$, Yanendra \\ Kumar Singh $^{2}$, and Rajesh Kumar ${ }^{2}$ \\ ${ }^{1}$ Department of Soil Science and Agricultural Chemistry, Bihar Agricultural University, Sabour, Bhagalpur-813210 \\ (Bihar), INDIA \\ ${ }^{2}$ Department of Plant Pathology, Bihar Agricultural University, Sabour, Bhagalpur-813210 (Bihar), INDIA \\ ${ }^{3}$ Department of Agronomy, Bihar Agricultural College, Bihar Agricultural University, Sabour, Bhagalpur-813210 \\ (Bihar), INDIA \\ *Corresponding author. E- mail: rbinnu@gmail.com
}

Received: September 22, 2014; Revised received: February 14, 2015; Accepted: February 20, 2015

Abstract: A field experiment was conducted to investigate the impact of resource conservation technologies on soil health and productivity of wheat in rice-wheat cropping system in split plot design with three replications. The physico-chemical parameters of the soils like $\mathrm{pH}$ and EC both maximum decreased almost significantly over control under treatments $T_{2}$ (Ploughing twice by Cultivator, allowed to decompose weeds for a week then puddling by cross ploughing and planking), $T_{3}$ (Summer ploughing onset of monsoon by mould bold plough to invert the soil once in three years followed by subsequent ploughing by cultivator to puddle the soil) and $\mathrm{C}_{5}$ (GM + Paddy straw @ 50 q/ ha) and $\mathrm{C}_{6}(\mathrm{GM}+$ Rice husk @ $50 \mathrm{q} / \mathrm{ha})$. Soil data revealed a highly significant increase in organic carbon content along with available $\mathrm{N}, \mathrm{P}_{2} \mathrm{O}_{5}$ and $\mathrm{K}_{2} \mathrm{O}$ content under treatments $\mathrm{T}_{3}$ and $\mathrm{C}_{6}$ and their interactions $\left(\mathrm{T}_{3} \times \mathrm{C}_{6}\right)$ over control. This might be attributed to the improvement in physico-chemical properties of the soils. The significant $(\mathrm{P}<0.05)$ increase in yield attributes and yields of wheat grain and straw over control was observed under influence of the treatments $T_{3}$ and $C_{6}$ and their interaction except height and length of ear head. These observations were confirmed by the positive and highly significant correlation of yield of wheat grain with available $N\left(r=0.74^{* *}\right)$, available $\mathrm{P}_{2} \mathrm{O}_{5}\left(r=0.64^{* *}\right)$, and available $\mathrm{K}_{2} \mathrm{O}\left(r=0.52^{* *}\right)$. Deep ploughing and green manuring in addition with other organic residues (GM+ rice husk) individually and/ or in combination improved the soil health significantly.

Keywords: Green manuring, Ploughing, Rice husk, Wheat

\section{INTRODUCTION}

Protection of soil health under intensive land use and fast economic development is a major challenge for sustainable resource use in the developing world. The basic assessment of soil health is necessary to evaluate the changing trends following different land use and management interventions. In Asia, adverse effects on soil health arise from nutrient imbalance in soil, excessive fertilization, soil pollution and soil loss processes (Swaminathan, 2006).

The concept of soil health has consistently evolved with an increase in the understanding of soils. Soil health cannot be measured directly, but soil properties that are sensitive to changes in management can be used as indicators. On-farm assessment of soil health is recommended to assist farmers evaluate the effects of their management decisions on soil productivity (Hobbs and Morris, 1996).

Cropping system refers to temporal and spatial arrangements of crops and management of soil, water and vegetation in order to optimize the biomass/ agronomic production per unit area, per unit time and per unit input. Three components of soil health (e.g. physical, chemical and biological) are determined by soil characteristics, which can be altered by management practices followed under various cropping systems (Liebig et al., 2004). Lal (1994) suggested that soil degradation, caused by land misuse and soil mismanagement, should be quantified by measuring management -induced changes in soil properties or processes and their impacts on actual and potential productivity. Establishment of the cause-effect relationship between soil properties and processes on the one hand and crop productivity and environmental moderating functions on the other is crucial to enhancing soil productivity, restoring degraded lands and improving environmental quality.

Intensive cultivation of agricultural soils can lead to deterioration in soil properties and consequently reduction in crop productivity. Thus, the need for tillage has been questioned in the last few decades because of the excessive erosion from farmland after tillage. At the same time, it is known that inappropriate use of 
applied inputs and overexploitation of natural resource base, principally land and water, in many situations in past had led to secondary salinization in low-quality aquifer zones, groundwater table recession in fresh water aquifer zones, physical and chemical deterioration of the soil and water quality due to nutrient mining and pollution of ground water in some locations due to over application of nitrogenous fertilizers and of environment through crop residue burning and pesticide use (Pingali and Shah, 2001; Gupta et al., 2003). Site-specific farming has introduced a management practice by which farmers can begin analyzing and dealing with cropland variability. Site-specific farming is based upon the notion that fields used for agricultural production are not uniform.

Rice-wheat systems of the eastern IGP have remained largely labor intensive and less mechanized. Farmers use low inputs because of socio-economic constraints and serious problems of drainage congestion and rainwater management. In the IGP, new resource conserving technologies for proper land and water management are being developed for enhancing crop productivity. Resource-conserving technologies are defined here as any practice that improves the efficiency of use of natural resources, including water, air, fossil fuels, soils, inputs, and people. Adoption of the resource conserving technologies offers newer opportunities of better livelihood for the resource poor small and marginal farmers. At the same time, these technologies are generating alternative sources of productivity growth through diversification and intensification of production systems (Hobbs and Gupta, 2003).

Now the main issue is regarding the selection of appropriate resource conservation technology for a given soil type, climatic condition and crop. Since not much work has been done on development of RCT's for different regions of IGP, the present investigation was formulated so in order to evaluate the impact of resource conservation technologies on the soil environment and productivity of wheat in rice-wheat cropping system.

\section{MATERIALS AND METHODS}

A field experiment was conducted during 2009-2011 to study residual impact of resource conservation technologies on soil health and productivity of wheat in rice-wheat cropping system with wheat as test crop (Tables 1 and 2). The experimental site is situated $25^{\circ} 15^{\prime} 40^{\prime \prime}$ North latitude and $87^{\circ} 21^{\prime} 42^{\prime \prime}$ East longitude with an altitude of $45.75 \mathrm{~m}$ above MSL (mean sea level). The sub-tropical climate of the area is characterised by dessicating summer and moderate rainfall. The total rainfall during the crop period was $78.6 \mathrm{~mm}$. Distribution pattern of rainfall during early period of crop growth was nil. The soil of experimental site was clay in texture with $\mathrm{pH} 8.3, \mathrm{EC} 0.38 \mathrm{dSm}^{-1}$ at $25^{\circ} \mathrm{C}$, organic carbon 0.58 per cent, available nitrogen $311 \mathrm{~kg} / \mathrm{ha}$, available $\mathrm{P}_{2} \mathrm{O}_{5} 36 \mathrm{~kg} / \mathrm{ha}$ and available $\mathrm{K}_{2} \mathrm{O} 205 \mathrm{~kg} / \mathrm{ha}$ as estimated by international pipette method (Kilmer and Alexander,
1949), soil-water suspension method, titration method (Walkley and Black, 1934), alkaline $\mathrm{KMnO}_{4}$ (Subbaiah and Asija, 1956), Olsen method (Olsen et al., 1954) and neutral normal ammonium acetate (Jackson, 1973), respectively were determined.

The experiment was conducted during Kharif season under irrigated conditions in split plot design (SPD) replicated thrice and their impact was tested in rabi wheat. Main plot treatments comprising of tillage (T) were:

$\mathrm{T}_{1}=$ Ploughing with desi plough twice (Cross) left for one week to decompose the weeds and residues and then planking in standing wheat (puddling) for paddy cultivation

$\mathrm{T}_{2}$ = Ploughing twice by Cultivator, allowed to decompose weeds for a week then puddling by cross ploughing and planking

$\mathrm{T}_{3}=$ Summer ploughing onset of monsoon by mould bold plough to invert the soil once in three years followed by subsequent ploughing by cultivator to puddle the soil.

$\mathrm{T}_{4=}$ Disc ploughing once in three years after onset of monsoon to invert the soil. Residues were incorporated by cultivator then puddling was done after one week.

Sub-plot treatments related to organic residues and green manuring $(\mathrm{C})$ were:

$\mathrm{C}_{1}=$ Control; $\mathrm{C}_{2}=$ FYM @ 50 q/ha; $\mathrm{C}_{3}=$ Paddy straw (a) $50 \mathrm{q} / \mathrm{ha} ; \mathrm{C}_{4=}$ Green manuring with Dhaincha (incorporated $45 \mathrm{DAS}$ ); $\mathrm{C}_{5}=\mathrm{GM}+$ Paddy straw @ 50 q/ha, $\mathrm{C}_{6=} \mathrm{GM}+$ Rice husk@ 90 q/ha

\section{RESULTS AND DISCUSSION}

Soil pH : The tillage treatments in same cropping system did not show any significant $(\mathrm{P}<0.05)$ change in $\mathrm{pH}$ over control, while significant change in $\mathrm{pH}$ under influence of the treatment of organic residues was observed (Table 3). This effect of tillage on change in $\mathrm{pH}$ was inconformity with the findings of Hargroves et al. (1982) who reported more rapidly decrease in $\mathrm{pH}$ under on tillage. Further, the significant decrease in $\mathrm{pH}$ under influence of the treatments of organic residues might be attributed to the release of different organic acids as intermediate products during decomposition process solubilising salts, which were lost with leaching.

Sadana and Bajwa (1986) reported a decrease in $\mathrm{pH}$ of the soil on application of green manure and gypsum whereas Badnaur et al. (1990) observed similar results on incorporation of Subabul and sunhemp over fertilizer treatment alone in a vertisol. Haq et al. (2007) reported that lowest significant $(\mathrm{P}<0.05) \mathrm{pH}$ value was attained in treatment of $100 \% \mathrm{GR}$ (gypsum requirement) $+10 \mathrm{t} /$ ha FYM compared to other closely followed by $100 \%$ GR and 50\% GR + 10t/ha FYM represented 9, 6 and $4 \%$ reduction, respectively from control. Manure produces organic acids and $\mathrm{CO}_{2}$ to dissolve native $\mathrm{CaCO}_{3}$ to liberate more $\mathrm{Ca}^{2+}$ for replacement of $\mathrm{Na}^{+}$. Gal et al. (2007) reported that significant change may occur in zero tillage due to more addition of organic matter. 
Table 1. Characteristics of the soil.

\begin{tabular}{|c|c|c|}
\hline & & Soil characteristics \\
\hline 1 & Location & Northern Section of Bihar Agricultural College Farm, Sabour \\
\hline 2 & Family & Fine, mixed, hyperthermic, Vertic Haplustalf \\
\hline 3 & Soil colour & Grey D 5 Y 6/1, Dark grey (M5Y4/1) \\
\hline 4 & Parent material & Alluvium \\
\hline \multirow[t]{4}{*}{5} & Mechanical composition & \\
\hline & Sand & $24 \%$ \\
\hline & Silt & $31 \%$ \\
\hline & Clay & $45 \%$ \\
\hline 6 & Texture & Clay \\
\hline 7 & $\mathrm{pH}$ & 8.04 \\
\hline 8 & $\mathrm{EC}$ & $0.33 \mathrm{dSm}^{-1}$ at $25^{0} \mathrm{C}$ \\
\hline \multirow[t]{3}{*}{9} & Water stable aggregates & \\
\hline & Mean weight diameter & $0.478 \mathrm{~mm}$ \\
\hline & Aggregate of size $(>0.25 \mathrm{~mm})$ & $28.00 \%$ \\
\hline 10 & Hydraulic conductivity & $0.148 \mathrm{~cm} \mathrm{hr}^{-1}$ \\
\hline 11 & Bulk density & $1.44 \mathrm{Mg} \mathrm{m}^{-3}$ \\
\hline 12 & Soil strength & $9.10 \mathrm{MPa}$ \\
\hline 13 & Organic carbon & $0.62 \%$ \\
\hline 14 & Available N & $338.5 \mathrm{~kg} \mathrm{ha}^{-1}$ \\
\hline 15 & Available $\mathrm{P}_{2} \mathrm{O}_{5}$ & $48.0 \mathrm{~kg} \mathrm{ha}^{-1}$ \\
\hline 16 & Available $\mathrm{K}_{2} \mathrm{O}$ & $225.6 \mathrm{~kg} \mathrm{ha}^{-1}$ \\
\hline
\end{tabular}

Table 2. Agro-management adopted for wheat crops.

\begin{tabular}{lll}
\hline & Operation & Date of operation \\
\hline 1 & Variety & Sonalika \\
2 & Spacing & $23 \mathrm{~cm}$ row to row \\
3 & Seed rate & $120 \mathrm{~kg} \mathrm{ha}^{-1}$ \\
4 & Fertilizer dose & $100: 60: 40 \mathrm{~N}, \mathrm{P}_{2} \mathrm{O}_{5}$ and $\mathrm{K}_{2} \mathrm{O}$ \\
\hline
\end{tabular}

The effect of interactions of these tillage and organic residues treatments was non-significant. This slow change might be attributed to the buffering capacity of the soils. Similar results were also advocated by Muthuvel et al. (1979) and Badanur et al. (1990).

Electrical conductivity (EC): A significant $(\mathrm{P}<0.05)$ decrease in EC of the soils under the influence of the treatments of tillage and organic residues and their interactions both after harvest of paddy and wheat was observed (Table 3). Maximum decrease in EC was noted under the influence of the treatments $T_{3}$ and $C_{6}$. This could be ascribed chiefly to the effect of release of different organic acids as intermediate products during decomposition process solubilizing soluble salts which were lost with leaching enhanced under loosened soils as a result of tillage treatments. Chaudhary et al. (1981) found that the electrical conductivity of soil decreased on application of FYM while Badanur et al. (1990) studied the incorporation effect of Subabul and sunhemp.
Soil organic carbon content (\%): There was significant $(\mathrm{P}<0.05)$ increase in organic carbon $(\mathrm{OC})$ content of the soils under influence of the treatments of tillage operations and application of organic residues over control after both paddy and wheat harvest (Table 3). Moreover, the maximum increase in organic carbon was noted in case of treatments $\mathrm{T}_{3}$ (mould board ploughing) and $\mathrm{C}_{6}(\mathrm{GM}+$ rice husk). This might be attributed to the addition of organic carbon to the soils by organic residues with high organic carbon content and vigorous growth of roots of the crops under well tilled conditions as a result of tillage treatments.

Biswas and Khosla (1971) found that the organic carbon content of alluvial soil of Sabour (Bhagalpur) increased to $2.28 \%$ by regular application of organic manure. Sharma et al. (1988) reported that the organic wastes (Lantana litter, rice husk and saw dust) markedly increased the organic carbon content by 29, 19 and 18 percent, respectively over control in silty clay loam soil. Badanur and Malabasari (1996) also observed that the incorporation of Subabul and Sunhemp in conjunction with sorghum stuble increased the organic carbon content of soil significantly. Gal et al. (2007) assessed the impacts of long-term (28 years) tillage and crop rotation on OC content and depth distribution on a dark-colored Chalmers silty clay loam in Indiana from moldboard plow and no-till treatments. Distribution of OC with soil depth differed dramatically under the different 
Table 3. Changes in physico-chemical properties of the soils.

\begin{tabular}{|c|c|c|c|c|c|c|}
\hline & \multicolumn{2}{|c|}{ pH $(1: 2.5)$} & \multicolumn{2}{|c|}{$E C\left(d S ~ m^{-1}\right)$} & \multicolumn{2}{|c|}{$\mathrm{OC}\left(\mathrm{g} \mathrm{kg}^{-1}\right)$} \\
\hline & $\begin{array}{c}\text { After paddy } \\
\text { harvest }\end{array}$ & $\begin{array}{c}\text { After wheat } \\
\text { harvest }\end{array}$ & $\begin{array}{c}\text { After paddy } \\
\text { harvest }\end{array}$ & $\begin{array}{c}\text { After wheat } \\
\text { harvest }\end{array}$ & $\begin{array}{c}\text { After paddy } \\
\text { harvest }\end{array}$ & $\begin{array}{c}\text { After wheat } \\
\text { harvest }\end{array}$ \\
\hline $\mathrm{T}_{1}$ & 8.15 & 8.14 & 0.39 & 0.4 & 0.62 & 0.58 \\
\hline $\mathrm{T}_{2}$ & 8.10 & 8.09 & 0.37 & 0.37 & 0.62 & 0.85 \\
\hline $\mathrm{T}_{3}$ & 8.21 & 8.21 & 0.35 & 0.34 & 0.64 & 0.60 \\
\hline $\mathrm{T}_{4}$ & 8.15 & 8.12 & 0.36 & 0.35 & 0.63 & 0.60 \\
\hline $\operatorname{SEm} \pm$ & 0.040 & 0.104 & 0.012 & 0.013 & 0.004 & 0.007 \\
\hline $\begin{array}{l}C D \\
(P=0.05)\end{array}$ & NS & NS & 0.025 & 0.025 & 0.010 & 0.016 \\
\hline $\mathrm{C}_{1}$ & 8.22 & 8.21 & 0.41 & 0.41 & 0.58 & 0.56 \\
\hline $\mathrm{C}_{2}$ & 8.15 & 8.17 & 0.36 & 0.35 & 0.61 & 0.58 \\
\hline $\mathrm{C}_{3}$ & 8.20 & 8.19 & 0.36 & 0.37 & 0.61 & 0.58 \\
\hline $\mathrm{C}_{4}$ & 8.14 & 8.14 & 0.38 & 0.36 & 0.63 & 0.60 \\
\hline $\mathrm{C}_{5}$ & 8.09 & 8.08 & 0.36 & 0.35 & 0.65 & 0.60 \\
\hline $\mathrm{C}_{6}$ & 8.10 & 8.04 & 0.34 & 0.33 & 0.67 & 0.62 \\
\hline $\mathrm{SEm} \pm$ & 0.043 & 0.036 & 0.014 & 0.016 & 0.005 & 0.005 \\
\hline $\begin{array}{l}C D \\
(P=0.05)\end{array}$ & 0.176 & 0.073 & 0.029 & 0.030 & 0.011 & 0.010 \\
\hline
\end{tabular}

Table 4. Changes in chemical properties of the soils.

\begin{tabular}{|c|c|c|c|c|c|c|}
\hline & \multicolumn{2}{|c|}{ Available nitrogen $\left(\mathrm{kg} \mathrm{ha}^{-1}\right)$} & \multicolumn{2}{|c|}{ Available $\mathrm{P}_{2} \mathrm{O}_{5}\left(\mathrm{~kg} \mathrm{ha}^{-1}\right)$} & \multicolumn{2}{|c|}{ Available $K_{2} O\left(\mathrm{~kg} \mathrm{ha}^{-1}\right)$} \\
\hline & $\begin{array}{l}\text { After paddy } \\
\text { harvest }\end{array}$ & $\begin{array}{c}\text { After wheat } \\
\text { harvest }\end{array}$ & $\begin{array}{l}\text { After paddy } \\
\text { harvest }\end{array}$ & $\begin{array}{c}\text { After wheat } \\
\text { harvest }\end{array}$ & $\begin{array}{l}\text { After paddy } \\
\text { harvest }\end{array}$ & $\begin{array}{c}\text { After wheat } \\
\text { harvest }\end{array}$ \\
\hline $\mathrm{T}_{1}$ & 337.6 & 320.2 & 45.6 & 45.5 & 234.4 & 231.5 \\
\hline $\mathrm{T}_{2}$ & 338.6 & 320.6 & 47.4 & 46.6 & 236.7 & 236.1 \\
\hline $\mathrm{T}_{3}$ & 340.6 & 323.6 & 53.9 & 51.0 & 242.4 & 241.0 \\
\hline $\mathrm{T}_{4}$ & 341.9 & 324.0 & 50.9 & 49.5 & 240.3 & 239.3 \\
\hline $\mathrm{SEm} \pm$ & 0.545 & 0.533 & 0.768 & 0.768 & 1.526 & 1.589 \\
\hline $\mathrm{CD}(\mathrm{P}=0.05)$ & 1.335 & 1.304 & 1.879 & 1.880 & 3.735 & 3.889 \\
\hline $\mathrm{C}_{1}$ & 323.9 & 313.9 & 37.6 & 36.4 & 199.6 & 195.0 \\
\hline $\mathrm{C}_{2}$ & 339.6 & 319.8 & 49.5 & 48.2 & 235.8 & 232.0 \\
\hline $\mathrm{C}_{3}$ & 338.6 & 318.8 & 47.5 & 44.8 & 226.0 & 218.0 \\
\hline $\mathrm{C}_{4}$ & 342.1 & 322.5 & 51.0 & 50.5 & 244.3 & 240.7 \\
\hline $\mathrm{C}_{5}$ & 344.7 & 326.3 & 52.8 & 51.6 & 259.0 & 262.4 \\
\hline $\mathrm{C}_{6}$ & 349.7 & 331.1 & 57.6 & 57.3 & 267.0 & 263.6 \\
\hline $\operatorname{SEm} \pm$ & 0.342 & 0.349 & 0.605 & 0.612 & 1.551 & 1.471 \\
\hline $\mathrm{CD}(\mathrm{P}=0.05)$ & 0.690 & 0.706 & 1.222 & 1.236 & 3.134 & 2.873 \\
\hline
\end{tabular}

tillage systems. While no-till clearly resulted in more OC accumulation in the surface layer than moldboard plow. Yadav et al. (2000) observed the long-term effect of green manuring and chemical fertilizer input practices utilising the trends in soil organic carbon content. At one location with high initial OC, a depletion of OC was noticed whereas $\mathrm{OC}$ increased at another location with low initial OC, with OC stabilizing between 0.60 and $0.65 \%$.

The values of organic carbon were higher after paddy harvest than that after wheat harvest. This might be attributed to anaerobic condition of paddy soils with slow decompositions of organic residues and aerobic conditions of the soils during wheat cultivation with faster decomposition of the organic residues followed by relatively higher loss of organic carbon. It might be further supported by the fact that anaerobic cultivation of paddy would have added more organic matter than that of aerobic wheat cultivation.

Available $\mathbf{N}\left(\mathrm{Kg} \mathrm{ha}^{-1}\right)$ : As revealed from the data (Table 4), the available $\mathrm{N}$ of the soils increased significantly $(\mathrm{P}<0.05)$ over control under influence of the treatments of tillage operations and application of organic residues and their interactions. The maximum increases in 
Table 6. Changes in growth and yield attributes of wheat plant.

\begin{tabular}{|c|c|c|c|c|c|c|c|}
\hline & $\begin{array}{c}\text { Height } \\
\text { (cm) }\end{array}$ & $\begin{array}{c}\text { Effective } \\
\text { tillers per } \\
\text { linear } \\
\text { meters }\end{array}$ & $\begin{array}{l}\text { Length of } \\
\text { ear head } \\
(\mathrm{cm})\end{array}$ & $\begin{array}{c}\text { Grain } \\
\text { per } \\
\text { panicle }\end{array}$ & $\begin{array}{c}1000 \text { grain } \\
\text { weight }(\mathrm{gm})\end{array}$ & $\begin{array}{c}\text { Grain } \\
\text { yield } \\
\left(\mathbf{q} \mathbf{h a}^{-1}\right)\end{array}$ & $\begin{array}{l}\text { Straw yield } \\
\left(\mathbf{q} \mathrm{ha}^{-1}\right)\end{array}$ \\
\hline $\mathrm{T}_{1}$ & 80.87 & 35.33 & 9.39 & 32.39 & 39.69 & 16.75 & 35.20 \\
\hline $\mathrm{T}_{2}$ & 84.00 & 35.77 & 9.45 & 32.99 & 39.71 & 17.46 & 35.63 \\
\hline $\mathrm{T}_{3}$ & 82.56 & 40.05 & 9.78 & 33.90 & 40.01 & 18.82 & 38.30 \\
\hline $\mathrm{T}_{4}$ & 79.72 & 36.72 & 9.39 & 33.21 & 39.73 & 18.16 & 37.63 \\
\hline $\mathrm{SEm} \pm$ & 0.649 & 0.346 & 0.209 & 0.389 & 0.988 & 0.314 & 0.553 \\
\hline $\mathrm{CD}(\mathrm{P}=0.05)$ & 1.589 & 0.846 & NS & 0.954 & NS & 0.767 & 1.365 \\
\hline $\mathrm{C}_{1}$ & 79.16 & 35.50 & 9.33 & 30.16 & 38.84 & 15.30 & 30.75 \\
\hline $\mathrm{C}_{2}$ & 81.95 & 36.00 & 9.78 & 32.77 & 39.81 & 17.72 & 34.65 \\
\hline $\mathrm{C}_{3}$ & 80.02 & 35.50 & 9.44 & 35.23 & 39.88 & 17.32 & 35.12 \\
\hline $\mathrm{C}_{4}$ & 83.25 & 37.08 & 9.64 & 33.45 & 39.97 & 17.69 & 37.90 \\
\hline $\mathrm{C}_{5}$ & 83.35 & 37.42 & 9.59 & 32.56 & 40.02 & 18.32 & 38.85 \\
\hline $\mathrm{C}_{6}$ & 83.00 & 40.33 & 9.58 & 33.88 & 40.20 & 20.46 & 42.98 \\
\hline $\mathrm{SEm} \pm$ & 1.289 & 0.529 & 0.197 & 0.554 & 0.095 & 0.253 & 0.573 \\
\hline $\mathrm{CD}(\mathrm{P}=0.05)$ & 2.605 & 1.068 & NS & 1.119 & 0.192 & 0.512 & 1.578 \\
\hline
\end{tabular}

available $\mathrm{N}$ was noted in $\mathrm{T}_{3}$ (Mould board ploughing) and $\mathrm{C}_{6}(\mathrm{GM}+$ rice husk $)$ and their interactions $\left(\mathrm{T}_{3} \times \mathrm{C}_{6}\right)$ and minimum under $\mathrm{T}_{1}$ (desi plough) and $\mathrm{C}_{3}$ (Paddy straw) and their interaction $\left(\mathrm{T}_{1} \times \mathrm{C}_{3}\right)$ (Table 5). It might be probably due to addition of available $\mathrm{N}$ by organic residues and larger root portions of the crops under well tilled conditions as a result of tillage treatments. It might be due to the fact that addition of organic residues and pulverised soil condition would have activated microbes for enhanced mineralization, which resulted into increase in available $\mathrm{N}$. It was further confirmed by the positive and highly significant correlation of available $\mathrm{N}$ with yield of wheat crop $(\mathrm{r}=0.74 * *)$ (Table 8). Singh and Verma (1995) revealed that deep tillage in the sub-surface sandy loam soil of Agra region improved available nitrogen contents. Sharma and Mitra (1991) observed that application of organic material with phosphorous increased the residual value of available $\mathrm{N}$ in soil after rice harvest and it was maximum noted in case of wheat straw and Azolla. The maximum increase in available $\mathrm{N}$ under $\mathrm{GM}+$ rice husk $\left(\mathrm{C}_{6}\right)$ might be attributed to the symbiotic $\mathrm{N}$-fixation by G.M. plants and quick decomposition of fresh plant residues. The values of available $\mathrm{N}$ were higher after paddy harvest than that after wheat harvest. Here, it might be accentuated that available $\mathrm{N}$ was more associated with organic carbon. Moreover, it might be due to more utilization of available $\mathrm{N}$ by the microbes engaged in faster mineralization under aerobic condition (Gattani et al., 1976).

Available $\mathbf{P}_{\mathbf{2}} \mathrm{O}_{\mathbf{5}} \quad\left(\mathrm{Kg} \mathrm{ha}^{-\mathbf{1}}\right)$ : There was significant $(\mathrm{P}<0.05)$ increase in available $\mathrm{P}_{2} \mathrm{O}_{5}$ over control under influence of the treatments of tillage operations $(\mathrm{T})$ and application of organic residues (C) and their interactions

Table 7. Interaction effect of ploughing and residue on yield attributes of wheat crop

\begin{tabular}{|c|c|c|c|c|c|c|c|c|c|c|c|c|}
\hline & \multicolumn{4}{|c|}{ Effective tillers per linear meters } & \multicolumn{4}{|c|}{ Grain yield (q ha $\left.{ }^{-1}\right)$} & \multicolumn{4}{|c|}{ Straw yield $\left(q \mathrm{ha}^{-1}\right)$} \\
\hline & $T_{1}$ & $\mathbf{T}_{2}$ & $\mathbf{T}_{3}$ & $\mathbf{T}_{4}$ & $T_{1}$ & $\mathbf{T}_{2}$ & $T_{3}$ & $\mathbf{T}_{4}$ & $T_{1}$ & $\overline{T_{2}}$ & $T_{3}$ & $\mathbf{T}_{4}$ \\
\hline $\mathrm{C}_{1}$ & 34.00 & 32.66 & 39.33 & 36.00 & 15.02 & 15.13 & 15.00 & 16.03 & 31.10 & 28.50 & 33.00 & 30.40 \\
\hline $\mathrm{C}_{2}$ & 33.33 & 36.00 & 36.66 & 38.00 & 16.69 & 17.14 & 19.76 & 17.30 & 35.20 & 33.80 & 35.60 & 34.00 \\
\hline $\mathrm{C}_{3}$ & 32.66 & 34.66 & 39.33 & 35.33 & 16.88 & 17.36 & 18.08 & 16.97 & 35.30 & 34.30 & 36.20 & 34.70 \\
\hline $\mathrm{C}_{4}$ & 36.66 & 37.33 & 38.33 & 36.00 & 16.08 & 17.47 & 18.64 & 18.56 & 35.00 & 38.10 & 40.90 & 37.60 \\
\hline $\mathrm{C}_{5}$ & 36.66 & 35.33 & 42.00 & 35.66 & 17.05 & 17.92 & 19.47 & 18.86 & 35.40 & 37.80 & 40.60 & 41.60 \\
\hline \multirow[t]{4}{*}{$\mathrm{C}_{6}$} & 38.66 & 38.66 & 44.66 & 39.33 & 18.82 & 19.72 & 21.99 & 21.26 & 39.20 & 41.60 & 43.50 & 47.60 \\
\hline & & & $\mathrm{SE}( \pm)$ & $\begin{array}{c}\text { CD } \\
(5 \%)\end{array}$ & & $\mathrm{SE}( \pm)$ & $\begin{array}{c}\text { CD } \\
(5 \%)\end{array}$ & & & $\mathrm{SE}( \pm)$ & $\begin{array}{c}C D \\
(5 \%)\end{array}$ & \\
\hline & \multicolumn{2}{|c|}{$\mathrm{C}$ at same $\mathrm{T}$} & 1.056 & 2.187 & & 0.507 & 1.091 & & & 1.146 & 2.423 & \\
\hline & \multicolumn{2}{|c|}{$\mathrm{T}$ at same $\mathrm{C}$} & 1.025 & 2.121 & & 0.559 & 1.203 & & & 1.186 & 2.507 & \\
\hline
\end{tabular}


Table 8. Correlation coefficient between soil and plant parameters.

\begin{tabular}{lccccccc}
\hline & Av. $\mathbf{~}$ & $\mathbf{A v} . \mathbf{P}_{\mathbf{2}} \mathbf{O}_{\mathbf{5}}$ & $\mathbf{A v} . \mathbf{K}_{\mathbf{2}} \mathbf{O}$ & $\mathbf{p H}$ & $\mathbf{E C}$ & Plant height & Wheat yield \\
\hline Av. $\mathbf{N}$ & 1 & $0.688^{* *}$ & $0.785^{* *}$ & $-0.526^{* *}$ & 0.125 & 0.326 & $0.744^{* *}$ \\
Av. $\mathbf{P}_{2} \mathbf{O}_{5}$ & & 1 & $0.852^{* *}$ & -0.164 & -0.218 & $0.522^{* *}$ & $0.643^{* *}$ \\
Av. $\mathbf{K}_{2} \mathbf{O}$ & & & 1 & $-0.411^{*}$ & 0.196 & 0.393 & $0.519^{* *}$ \\
pH & & & & 1 & -0.252 & -0.189 & -0.316 \\
EC & & & & & 1 & -0.216 & -0.270 \\
Plant height & & & & & & 1 & 0.272 \\
Wheat yield & & & & & & & 1 \\
\hline
\end{tabular}

$* 5 \%$ level of significance, $* * 1 \%$ level of significance

$(\mathrm{T} \times \mathrm{C})$ (Tables 4 and 5). The maximum increase in available $\mathrm{P}_{2} \mathrm{O}_{5}$ was observed in case of mould board ploughing $\left(\mathrm{T}_{3}\right)$ and green manuring + rice husk $\left(\mathrm{C}_{6}\right)$ and their interactions $\left(\mathrm{T}_{3} \times \mathrm{C}_{6}\right)$ and minimum in a case of desi plough $\left(\mathrm{T}_{1}\right)$ and paddy straw $\left(\mathrm{C}_{3}\right)$ and their interactions $\left(\mathrm{T}_{1} \times \mathrm{C}_{3}\right)$. The increase in available $\mathrm{P}_{2} \mathrm{O}_{5}$ on application of treatments might be probably due to addition of $\mathrm{P}_{2} \mathrm{O}_{5}$ by organic residues larger amount of roots of the growing crops under well tilled condition as a result of tillage operations. It might be further supported by the fact that addition of organic residues and pulverized soil condition would have activated phosphobacterins of enhanced transformation of organic $\mathrm{P}$ of the organic residues, which resulted into increase in available $\mathrm{P}_{2} \mathrm{O}_{5}$. It was further confirmed by the positive and highly significant correlation of available $\mathrm{P}_{2} \mathrm{O}_{5}$ with plant height $\left(\mathrm{r}=0.52^{* *}\right)$ and yield of wheat crop $\left(\mathrm{r}=0.64^{* *}\right)$ (Table 8). Pandey et al. (1985) observed that the wheat straw incorporation was most effective in increasing the available $\mathrm{P}$ and Saha et al. (1995) find same result on application of barseem + straw, bagasse + rice straw. Badanur and Malabasari (1996) also observed that the incorporation of Subabul and Sunhemp in conjunction with sorghum stubble increased the organic carbon content of soil significantly. Carter and Rennie (1982) observed that the available P was significantly higher under 16 years of continuous use of zero tillage than the conventional shallow tillage in the surface soil. Similarly, the continuous direct drilling caused a marked increase in $\mathrm{P}$ content in the top soil than ploughing, chisel ploughing and reduced tillage (Millard and Vez, 1982).

Moreover, the beneficial effect of organic residues might also be due to formation of organic phosphate and release of inherent $\mathrm{P}$ from the organic residues. Further, the formation of organic acids as intermediate products due to decomposition of green manuring materials might have contributed towards the maximum response of $\mathrm{C}_{6}$ in increasing available $\mathrm{P}_{2} \mathrm{O}_{5}$.

Available $\mathrm{K}_{\mathbf{2}} \mathrm{O}\left(\mathrm{Kg} \mathrm{ha}^{-\mathbf{1}}\right)$ : Significant $(\mathrm{P}<0.05)$ increase in available $\mathrm{K}_{2} \mathrm{O}$ over control under influence of the treatments of tillage operations $(\mathrm{T})$ and application of organic residues $(\mathrm{C})$ and their interactions $(\mathrm{T} \times \mathrm{C})$ (Table 4 and 5) were observed. The maximum increase was noted under tillage treatment $\mathrm{T}_{3}$ (Mould board
Ploughing) and organic residues $\mathrm{C}_{6}(\mathrm{GM}+$ rice husk) and minimum under $\mathrm{T}_{1}$ (Desi plough) and $\mathrm{C}_{3}$ (paddy straw). This might be attributed to high $\mathrm{K}$ reserves of the organic residues and release of native $K$ under microbiological decomposition as evident from the high organic carbon of the treated plots. It might be supported by the fact that the $\mathrm{NH}_{4}{ }^{+}$ions which were increased due to faster ammonification (mineralization) by the ammonifiers would have exchanged $\mathrm{K}^{+}$and released them from the exchange complex resulting in increases in available $\mathrm{K}_{2} \mathrm{O}$. Ruhal and Shukla (1979) reported that available $\mathrm{K}$ decreased from 498 to 318 $\mathrm{kg} /$ ha due to continuous cropping without FYM. However, continuous application of FYM for 9 years increasd the availability of $\mathrm{K}$ to $655 \mathrm{~kg} / \mathrm{ha}$ and the highest $\mathrm{K}$ content was noted when FYM was applied in both the seasons. The relative build-up of $\mathrm{K}$ was more when FYM was applied to winter crop than that of monsoon. Pandey et al. (1985) observed that addition of all organic material and fly ash gave significant increase in $\mathrm{K}$ status of soil. Similarly, Subabul and subabul with sorghum stuble significantly increased available $\mathrm{K}$ content in soil (Badanur et al., 1995). Hargroves et al. (1982) indicated an increase in available $\mathrm{K}_{2} \mathrm{O}$ under influence of continuous 5 years no tillage.

Maximum values of available $\mathrm{K}_{2} \mathrm{O}$ (268.8 and 276.2 $\mathrm{kg} \mathrm{ha}^{-1}$ ) might be ascribed chiefly to the effect of faster decomposition of green manuring materials and higher $\mathrm{K}$ content of GM and rice husk as supported by deep ploughing (Mould board ploughing) which ultimately provided maximum sites for $\mathrm{NH}_{4}^{+}$and $\mathrm{K}^{+}$interactions in soil under loosened condition. The results were supported by the positive highly significant correlation of available $\mathrm{K}_{2} \mathrm{O}$ with yield of wheat $\left(\mathrm{r}=0.52^{* *}\right)$ (Table 8).

Yield attributes and yield of wheat crop: The data on yield attributes (heights, number of effective tillers /linear meter, length of ear head, number of grains /panicle and 1000 grain weight) and yield of wheat grain and straw presented in table 6 revealed that significant $(\mathrm{P}<0.05)$ increase almost in all these characters over control with a few exception under influence of the treatments of tillage operations and application of organic residues.

Maximum increase in yield attributes and yield of wheat grain and straw was under influence of the treatments 
Mould board ploughing $\left(\mathrm{T}_{3}\right)$ and $\mathrm{GM}+$ rice husk $\left(\mathrm{C}_{6}\right)$. With few exception of height and length of ear head where $T_{2}$ (cultivator) and $C_{2}$ (FYM) were found most effective. It was observed that the minimum increase in yield attributes was under influence of the common tillage treatment $\mathrm{T}_{1}$ (Desi plough) and variable organic residue treatments like $\mathrm{C}_{2}, \mathrm{C}_{3}$ and $\mathrm{C}_{5}$. But, the effect of $\mathrm{C}_{3}$ treatment seemed to be general with exception of $\mathrm{C}_{2}$ and $\mathrm{C}_{5}$.

Moreover, some of the characters did not show correlation among themselves. It might be attributed to the deviation in such characters from that of optimum varietal characters. On the basis of highest height of the plant, it could not be aimed at highest yield of straw, because straw yield would not only depend on only height of the plants, but also on number of effective tillers and diameter and thickness of wheat shoot. However, a positive correlation of yield of wheat grain with plant height $(\mathrm{r}=$ 0.27 ) was noted.

The maximum increase in the yield of wheat grain and straw was under influence of the tillage treatment $T_{1}$ (Desi plough), $\mathrm{C}_{2}$ (FYM) and $\mathrm{C}_{3}$ (Paddy straw) and their interactions (Table 7). The increase in yields might be ascribed chiefly to the effect of tillage and organic residues treatments on the improvement of physical, physico-chemical and chemical properties of the soils along with the availability of nutrients. These observations were further confirmed by positive and highly significant correlation of yield of wheat grain with that of available $\mathrm{N}\left(\mathrm{r}=0.74^{*}\right)$, available $\mathrm{P}_{2} \mathrm{O}_{5}(\mathrm{r}=$ $0.64 * *)$, and available $\mathrm{K}_{2} \mathrm{O}(\mathrm{r}=0.52 * *)$ (Table 8$)$. It was supported by the previous finding of Ghildyal (1978) who was of the opinion that the tillage methods were known to favourably moderate soil physical environment for efficient water and nitrogen management and higher grain yield of rice. Kavimandan et al. (1987) observed that organic amendments like wheat straw, rice straw and FYM increased seed and straw yield of wheat significantly, whereas Singh et al. (1991) reported that only one tillage cum sowing operation was enough for better plant establishment and higher grain yield of lentil.

Deep ploughing and treatment of green manuring (GM) in addition to other organic residues individually and in combination improved the soil characters significantly, which led to the maximum increase in yields of wheat grain and straw. Moreover, the contribution of different tillage and organic residues treatments and their interactions were evaluated in terms of degree of improvement of yield attributing characters which resulted in increased yield of wheat crop. Actually, the increase in yield attributes and yield of wheat crop was not only contributed by a single factor, but a combination of factors was responsible for that.

\section{Conclusion}

The results indicated a significant improvement in soil health along with yield attributes and yields of wheat grain and straw over control under influence of these treatments of tillage operations (T) and application of different organic residues and their interactions $(\mathrm{T} \times$ C). The maximum impact on improvement of soil health and plant parameters were observed under the treatments of $\mathrm{T}_{3}(\mathrm{MB})$ and $\mathrm{C}_{6}(\mathrm{GM}+$ rice husk) and their interactions $\left(\mathrm{T}_{3} \times \mathrm{C}_{6}\right)$. Positive and highly significant correlation of yield of wheat grain with available $\mathrm{N}$ $\left(\mathrm{r}=0.74^{* *}\right)$, available $\mathrm{P}_{2} \mathrm{O}_{5}\left(\mathrm{r}=0.64^{* *}\right)$, and available $\mathrm{K}_{2} \mathrm{O}\left(\mathrm{r}=0.52^{* *}\right)$ were observed. Moreover, the increase in yield attributes and yield of wheat crop was not only contributed by a single factor, but a combination of factors was responsible for such significant increase.

\section{REFERENCES}

Badanur, V.P. and Malabasari, T.A. (1996). Effect of recycling of organic residues on soil properties and yield of sorghum in vertisol. Indian Journal of Soil Conservation, 23:236-238.

Badanur, V.P., Poleshi, C.M. and Naik, B.(1990). Effect of organic matter on crop yield, physical and chemical properties of vertisol. J. Ind. Soc. Soil Sci., 38: 426-429

Biswas, T.D., and Khosla, B.K. (1971). Building up of organic matter status of the soil and its relation to the physical properties of soil. Soil Science Society of America Journal, 19: 31-37.

Carter, M.R., and Rennie, D.A. (1982). Changes in soil quality under zero tillage farming systems: Distribution of microbial biomass an mineralizable C and N potentials. Can. J. Soil Sci., 62:587-597.

Chaudhary, M.L., Singh, J.P. and Narwal, R.P. (1981). Effect of long term application of $\mathrm{P}, \mathrm{K}$ and FYM on some soil chemical properties. J. Ind. Soc. Soil Sci., 29:81-85.

Gal, A., Vyn, T.J., Micheli, E., Kladivko, E.J. and McFee, W.W. (2007). Soil carbon and nitrogen accumulation with long term no-till versus moldboard plowing overestimated with tilled-zone sampling depths. Soil and Tillage Research, 96: 42-51.

Gattani, P.D., Jain, S.Y., and Seth, P.Y. (1976). Effect of continuous use of chemical fertilizer and manures on soil physical and chemical properties. Indian Soc. Soil Sci., 24: 284-289.

Ghildyal, B.P. (1978). Effects of compaction and puddling on soil physical properties and rice growth. Soils and Rice. International Rice Research Institute, Los Baños, Philippines

Gupta, R.K., Listman, G.M. and Harrington, L. (2003). The Rice-Wheat Consortium for the Indo-Gangetic Plains: Vision and management structure. In: Addressing Resource Conservation Issues in Rice-Wheat Systems of South Asia: A Resource Book. Rice-Wheat Consortium for the Indo -Gangetic Plains. Intl. Maize and Wheat Improvement Centre., New Delhi, India. 1-7

Haq, I., Muhammad, B. and Iqbal, F. (2007). Effect of 
gypsum and farmyard manure on soil properties and wheat crop irrigated with brackish water. Soil and Environ. 26:164-171.

Hargroves, W.L., Reid, J.T., and Gallaher, R.N. (1982). Influence of tillage practices on the fertility status of an acid soil double cropped to wheat and soybeans. Agron. J., 74: 684-687.

Hobbs, P. and Gupta, R. (2003). Problems and Challenges of No-Till Farming for the Rice-Wheat Systems of the Indo-Gangetic Plains in South Asia. In Lal, R., Hobbs, P., Hansen, D.O., and Uphoff, N. (eds.), Sustainable Agriculture and the RiceWheat System, Marcel Dekker, New York, in press.

Hobbs, P.R., and M.L. Morris. 1996. Meeting South Asia's Future Food Requirements from Rice -Wheat Cropping Systems: Priority Issues Facing Researchers in the Post Green Revolution Era. NRG Paper 96-01. Mexico, D.F.: CIMMYT.

Jackson, M.L. (1973). In Soil Chemical Analysis. Pentice Hall of India Pvt. Ltd., New Delhi.

Kavimandan, S.K., Gupta, J.P. and Mahapatra, I.C. (1987). Studies on residue management and biofertilizers in rice-wheat sequence. Indian $J$. Agron., 32(3): 278-279.

Kilmer, V.J. and L.T. Alexander. (1949). Methods of making mechanical analysis of soils. Soil Sci. $68: 15-24$.

Lal, R. (1994). Methods and guidelines for assessing sustainable use of soil and water resources in the tropics. SMSS Technical Monograph, No. 21, Washington, DC.

Liebig, M.A., Tanaka, D.L. and Wienhold, B.J. (2004). Tillage and cropping effects on soil quality indicators in the northern Great Plains. Soil Tillage Res., 78: 131-141.

Millard, A. and Vez, A. (1982). Influence of different soil tillage implements on yields and on some chemical and physical soil prop. Proceeding of 9 th conference of the Int. soil tillage research organisation, Nyon, Switzerland.

Muthuvel, P., Kandaswamy, P., and Krishnamoorthy, K.K. (1979). Soil pH electrical conductivity and CEC under long term fertilization. Madras Agricultural Journal, 66(5): 296-299

Olsen, S.R., Cole, C.V., Watanabe, F.S. and Dean, L.A. (1954). Estimation of available phosphorus in soils by extraction with sodium bicarbonate. U.S. Dep. of Agric. Circ. 939.

Pandey, S.P., Hari Sankar and Sharma, V.K. (1985). Efficiency of some organic and inorganic residues in relation to crop yield and soil characteristics.
Journal of the Indian Society of Soil Science, 33 (1): 179-181

Pingali, P.L. and Shah, M. (2001). Policy re-directions for sustainable resource use: the rice-wheat cropping system of the Indo-Gangetic Plains. Journal of Crop Production, 3:103-118.

Ruhal, D.S. and Shukla, U.C. (1979). Effect of continuous application of farmyard manure and nitrogen and carbon and available N, P and $\mathrm{K}$ content of soil. Indian Journal of Agricultural Chemistry, 12: 11-18.

Sadana, U.S. and Bajwa, M.S. (1986). Effect of gypsum and green manuring on electrochemical and chemical changes in submerged sodic soils. Oryza, 23: 89-95.

Saha, N., Das, A.C. and Mukherje, D. (1995). Effect of decomposit on of organic matter on the activites of micro rganisms and availability of nitrogen, phosphorus and sulphur in soil. Journal of the Indian Society of Soil Science, 43 (2): 210-215.

Sharma, A.R. and Mitra, B.N. (1991). Direct and residual effects of organic materials and phosphorus fertilizer in rice based cropping system. Indian J. Agron., 36: 299-303.

Sharma, P.K., De Datta, S.K. and Redulla, C.A. (1988). Tillage effects on soil physical properties and wetland rice yield. Agron. J., 80: 34-39.

Singh, P. and Verma, R.S. (1995). Effect of tillage depth, sowing methods and $\mathrm{N}$ fertilization on soil properties and root development of pearlmillet. Indian Journal of Soil Conservation, 23(2): 135 -139 .

Singh, S.P., Tomar, S. and Singh, R.R. (1991). Effect of tillage, seed rates and irrigation on the growth, yield and quality of lentil. Indian $J$. Agron., 36:143-147.

Subbaiah, B.V. and Asija, G.L. (1956). A rapid procedure for the determination of available nitrogen in soils. Curr. Sci. 25: 259-60.

Swaminathan, M.S. (2006). $5^{\text {th }}$ Report on National commission of Farmers: Serving Farmers And Saving Farming. Submitted to Ministry of Agriculture, GOI.

Walkley, A.J. and Black, C.A. (1934). An estimation of the DegtJardt metnod for determining soil organic matter and a proposed modification of the chromic acid titration method. Soil Sci., 37: 29-38.

Yadav, R.L., Dwivedi, B.S., Pandey, P.S. (2000). Rice -wheat cropping system: assessment of sustainability under green manuring and chemical fertilizer inputs. Field Crops Research, 65: 15-30. 